\title{
JUURNAL_RU
}

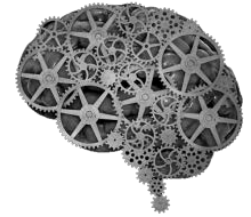

COMPANY GROUP "INTELLEKT"

\author{
Давыдов И.В. \\ Казанский Федеральный Университет. \\ Институт международных отношений, истории и востоковедения \\ Казань, Россия
}

doi: 10.18411/lj2016-3-66

\section{Преобразование системы военного образования России во второй половине XIX века по итогам Крымской войны 1853-1856 годов}

Исторический опыт реформ в России во второй половине XIX века и в наше время представляет собой богатый практический материал для анализа и практических рекомендаций в ходе современных реформ, проводимых в нашей стране.

Причинами любого реформирования в стране, как правило, являются неудачи действий правительства и критическое осмысление причин, породивших их. Одной из самых значимых реформ, проведенных во второй половине XIX века, является военная реформа. Неудачи в Крымской войне 18531856 годов, выявили проблемные вопросы военного строительства, требующие значительной корректировки и решения на государственном уровне. Такими вопросами стали:

- несоизмеримые финансовые затраты на армию, выражающиеся в расходах на материально-техническое обеспечение армии, содержание излишне раздутого и громоздкого штата численности войск, неоправданные расходы на обучение офицерского корпуса и др.

- низкая боеспособность армии, заключающаяся в неудовлетворительной системе управления всего военного министерства, слабой обученности солдат и офицерского корпуса, отсутствии современного нарезного оружия и использовании устаревшей линейной тактики ведения боя. 
Любая война во все времена несет стране огромные убытки людских и материальных ресурсов, но в Крымской войне 1853-1856 г. большая часть убыли всевозможных ресурсов напрямую зависело от умения правительства перевести государство на военное положение и способностью обеспечить армию всеми необходимыми материальными средствами, а от военного министерства умения ведения военной компании. К сожалению, бюрократия, некомпетентность и злоупотребления должностных лиц прочно вросли в систему государственного и военного управления. Исследователь А. Трубецкой в своей книге «Крымская война» пишет: - «..огромные человеческие и материальные затраты, связанные с этой войной, перешли все границы допустимого. По оценкам война стоила русской казне 142 миллиона фунтов стерлингов (в пересчете на современную покупательную способность около 8,5 миллиарда), то есть всего лишь на 15\% меньше суммарных расходов Франции и Англии...» [12 c.308]. И хотя в самом военном министерстве выделение материальных средств осуществлялось в достаточных объемах, до войск снабжение доходило в самом неприглядном виде. А.А.Керсновский отмечал: «...Злоупотребления в интендантской части превзошли все наблюдавшиеся до сих пор.... Все запасы хлеба, сена, овса, рабочего скота, лошадей, телег - все было направлено к услугам армии. Но армия терпела постоянный недостаток в продовольствии; кавалерия, парки не могли двигаться. Зато командиры эскадронов, батарей и парков потирали руки...»[8 с.492].

Страшнейшая централизация управления, царившая в армии, значительно понижала ее боевую готовность и губила любую разумную инициативу на местах. Все решения по военному ведомству проходили длительную цепочку бюрократических согласований и утверждений со стороны высших органов управления, что отрицательно сказывалось на своевременности принятия нужных решений и в то же время, центральные органы управления армией зачастую не знали о состоянии дел в подчиненных войсках и ведомствах из-за сложной системы делопроизводства и представления документов через 
различные коллегии и всевозможные инстанции. Военное министерство и военный совет погрязли в рассмотрении мелких дел, которые по определению должны решаться на местах, но ввиду отсутствия права у местных департаментов принимать решения, например, финансовые, которые по существующим правилам должны были утверждаться только у высшего руководства, количество рассматриваемых бумаг было огромно, а смысловое значение их ничтожно. При таком положении дел сам военный министр не мог в должной мере влиять на развитие любых отраслей военного ведомства.

Одной из главных причин низкой боеспособности армии являлось неумение офицеров командовать, отсутствие боевой подготовки у солдат, устаревшая линейная тактика ведения боя на равнинной местности. А.А Керсновский в своем труде обобщает свидетельства очевидцев «профессионализма офицеров»: «Тут - генералы, заколотые в штыковом бою, но своевременно не сумевшие распорядиться... Сбивчивые приказания и путаные контрмарши... Застывший под ядрами строй, смыкающий ряды и подравнивающий носки в ожидании приказа, который будет отдан лишь тогда, когда окажется невыполнимым... Батальный огонь, не причиняющий особенного вреда противнику; колонны, атакующие в ногу, с соблюдением равнения на середину, с потерей половины состава — и без всякого результата...».[8 с. 489]

Проблемы офицерского корпуса состояли, в первую очередь, в профессиональной подготовке офицерского корпуса. Многочисленные историки и исследователи причин неудач в Крымской войне 1853-1856 годов (В.Э. Багдасарян, И.В. Бестужев, А.М. Зайончковский, Е.В. Тарле, А.И. Каменев и др. ) отмечают отсутствие плановой подготовки офицеров и солдат, а сами современники отмечали: «...Солдат учили только выправке, ружейным приемам и умению маршировать...», «...у многих начальников наука не только не находила покровительства, а напротив встречала преследование, насмешку: занимающегося наукою офицера обыкновенно называли «ученым», прилагая это название преимущественно в тех случаях, когда ему случалось сделать какой- 
нибудь промах...»[2 с.12]. Историк А.И. Каменев в своем исследовании, обобщая высказывания современников и историков об уровне подготовки офицеров, отмечает «однобокость подготовки офицерского корпуса России» 7 с.58], так как на первое место в профессионализме офицера ставилась парадная подготовка, а не его умение управлять солдатами в бою.

Таким образом причины поражений и назревшая необходимость проведения реформ в армии были очевидны, да и сами современники отмечали необходимость назревших перемен: «...В общем же русская армия, воевавшая у себя дома, потерпела поражение от неприятельского десанта, подвезенного за три тысячи верст! Жестокая расплата за сорок лет застоя. На язвы, раскрывшиеся решительно во всех отраслях нашей военной системы, и обратилось все внимание начинавшегося царствования...» [8 с.492]

Для решения этих проблем 30 августа 1860 года Александр II призывает на пост заместителя военного министра Дмитрия Алексеевича Милютина (18161912 г), а 9 ноября 1861 года назначает его военным министром.

15 января 1862 года Д.А. Милютин представил свой знаменитый всеподданнейший доклад о состоянии дел и предложения по переустройству всей военной системы Российской Империи. Данный доклад лег в основу программы переустройства военного управления армии, реализация которой явилась всеобъемлющая реформа всей военной системы.

Одним из наиболее значимых направлений программы переустройства армии, безусловно являлась реформа всей военно-образовательной деятельности, ее необходимость Д.А. Милютин отмечает в своих «Воспоминаниях»: «Тяжелый урок Крымской войны открыл нам глаза на многие важные недостатки нашей армии, которую мы прежде считали верхом совершенства. В особенности выказалась бесплодность существовавшей прежде системы обучения войск, вся непригодность для войны прежних педантических требований на плац-параде и в манеже». [11 c.254] 
Основой армии во все времена являлся его офицерский корпус. Именно от уровня профессионального военного образования и обученности офицеров во многом зависела боеспособность русской армии, Д.А. Милютин вспоминает: «В деле благоустройства и совершенствования армии имеет первостепенное значение - хороший офицерский состав. И в этом отношении тогдашнее положение наших войск нельзя было признать удовлетворительным». [11 с.257] Система военного образования офицеров которая существовала в России до середины XIX века изучалась целым рядом историков. Наиболее полно и обобщенно анализ системы военного образования представлена в трудах (А.М.Заойнчковского, М.С.Лалаева, Н.Н. Мельницкого). Так, А.М. Зайончковский отмечает: «Комплектование армии офицерами производилось при помощи: 1) выпуска из военно-учебных заведений, 2) производства, добровольно поступивших на службу нижними чинами и 3) производства нижних чинов, поступавших на службу по наборам. Военно-учебные заведения, дававшие право на выпуск офицерами, были: Пажеский и 15 кадетских корпусов, Школа гвардейских подпрапорщиков и юнкеров, Дворянский полк, Михайловское артиллерийское, Главное инженерное училища и Школа топографов» [6 стр.419]

В середине XIX века профессиональная подготовленность офицерских кадров нижнего звена управления (взвода, роты) оставляла желать лучшего, а его образованность была крайне низка, в качестве доказательства А.М. Зайончковский приводит свидетельство командира Колыванского пехотного полка полковника Пересветова: «..., например, офицеры 10-й пехотной дивизии были так малограмотны, что полковые командиры с трудом могли выбирать полковых адъютантов». [14 c.12] Доля офицеров, поступавших на укомплектование армии из кадетских корпусов составляла всего лишь (26\%). Так сам Д.А. Милютин отмечал, что: «...воспитанники кадетских корпусов и других военно-учебных заведений - составляли менышинство, служили почти исключительно в гвардии, в специальных родах оружия, в военных 
управлениях». [11 с.259], а остальные получали офицерский чин из войсковых юнкеров и унтер-офицеров (62\%) или из числа дворян, имеющих право на офицерский чин и призвавшихся из отставки на военную службу (12\%). [3 с.461] Финансирование обучения составляло ежегодно около 4.000.000 руб. Сумма же, выделяемая на обучение в кадетских корпусах, не оправдывала количество и качество выпускаемых в войска офицеров, [3 с.461] проведенный Д.А. Милютиным анализ показывает: «военно-учебные заведения в то время давали армии не более 650 офицеров, тогда как пополнение ежегодной убыли в офицерском составе требовало свыше 1600». [11 с.259]

Как и все направления военного ведомства, система военного образования, имела большие недостатки. Например, само управление военно-учебными заведениями с 1860 года было сосредоточено в штабе Его Императорского Высочества, в руках главного начальника этих заведений Великого Князя Михаила Павловича. Все касающееся военно-учебных заведений он докладывал напрямую Александру II, а военный министр мог при докладах и принятиях решений касаться деятельности военно-учебных заведений лишь в общих вопросах военного ведомства, т.е., фактически никак не влияя на его развитие. [9 c.302]

Таким образом выявился целый ряд проблем в военном ведомстве и системе его управления, одной из которых являлась отсутствие налаженной, единой системы военного образования.

Преобразования в системе военного образования в ходе проводимых реформ происходило в основном по следующим направлениям.

1. Установление единства в управлении всей военно-учебной части.

2. Отделение общего и специального образования.

3. Разработка программ обучения, соответствующих требованиям современного боя.

4. Повышение уровня образования всех военнослужащих. 
Проводимые преобразования в центральном военном управлении привели к тому, что 21 января 1863 года было сформировано главное управление военноучебных заведений, которое вошло в состав военного министерства. [15 с.79] Это управление организационно включало в себя штаб управления и управления училищ военного ведомства. Для улучшения руководства согласно подведомственности, из главного управления военно-учебными заведениями вывели: академию генерального штаба с переподчинением ее начальнику Главного штаба; Михайловскую артиллерийскую академию и Михайловское артиллерийское училище с переподчинением их Главному артиллерийскому управлению; Николаевскую инженерную академию и Николаевское инженерное училище с переподчинением их Главному инженерному управлению. [15 с.79]

Новые виды деятельности военного управления потребовали создание особых комитетов, которые разрабатывали различные методики и рекомендации для управления в определенной сфере военной деятельности. Так в главном управлении военно-учебных заведений был создан педагогический комитет, в котором обсуждались и передавались на утверждение к действию вопросы, связанные с обучением и воспитательной деятельностью, рассматривались и обсуждались учебные программы, руководства и пособия, возлагалась ответственность за издание журнала для чтения воспитанниками военноучебных заведений. [16 с.924]

При военном совете имевшим статус главного совещательного органа управления с распорядительными функциями, был создан главный военноучебный комитет, в который входили все начальники академий, военно-учебных заведений и их помощники. [16 c.924] Предназначение этого комитета заключалась в организации взаимодействия вопросов управления военноучебными заведениями между различными ведомствами в обсуждении и решении всех общих вопросов связанные с военными академиями и специальными училищами, а также всеми видами военно-учебных заведений. 
Для контроля за деятельностью военно-учебных заведений и проведения смотров и инспекций были введены должности членов военного совета и инспекторов военно-учебных заведений. [16 с.924]

С введение военно-окружной системы на начальника штаба округа были возложены обязанности контроля за строевым руководством и контролем в части его касающемся военно-учебных заведений, расположенных на территории округа с представлением ежегодного доклада военному министру.

Решением вопросов разделения общего и специального образования занималась комиссия при Инспекторском департаменте Военного министерства, предложениях которой легли в 1864 в основу положения по устройству юнкерских училищ.[17 с.610]

Особую роль в системе комплектования армии офицерами Д.А. Милютин отводил юнкерским училищам: «...Устройство юнкерских училищ, сколь можно в большем числе и в приличной обстановке, считал я одною из неотложных мер к обеспечению комплектования армии офицерами, если не вполне соответствующими требованиям современного военного дела в Европе, то по крайней мере несколько подготовленными к их служебной деятельности и общественному положению...». [11 с.259]. Как всегда, во время проведения реформ существовали сторонники и противники реформ, так упразднение кадетских корпусов многими современниками было воспринято как искоренение преемственности поколений и кастовости в становлении офицеров. Однако Д.А Милютин учитывал в первую очередь общий уровень образования офицеров, имеющийся на тот момент и интересы всей армии. «Главным рассадником офицеров армии неизбежно должны были оставаться юнкерские училища. Еще надолго необходимо было нам довольствоваться такими заведениями, сравнительно низшего разряда, которые стоили бы недорого и в которых учебный курс соответствовал бы степени развития наибольшей массы поступающих в армию молодых людей» писал в своих «Воспоминаниях» Д.А.Милютин [11 с.260]. 
После проведения всех преобразований система военно-учебных заведений обрела стройность и включает в себя: 1. военные гимназии или прогимназии - 2. военные училища (корпуса, юнкерские и специальные) - 3. военные академии.

1. Военные гимназии и прогимназии, пришли на смену кадетским корпусам и являлись, как описывают современники: «центром тяжести всей системы военно-учебных заведений, обладая хорошими средствами и будучи богато обставленными в учебновоспитательном отношении, вели свое дело спокойно и уверенно, проводя юношей более способных (а их было около 90\%) через весь свой курс в военные училища, а менее способных - через прогимназии в юнкерские училища, которые комплектовались и гражданскими учебными заведениями».[9 с.39]

2. В 1863 году к военным училищам относились следующие военноучебные заведения: Пажеский, Финляндский, Оренбургский, Сибирский кадетский корпус, Николаевское училище гвардейских юнкеров и три основных военных пехотных училища Павловское, Константиновское и Александровское, в дальнейшем были открыты юнкерские училища: пехотные - Московское, Виленское, Варшавское, Гельсингфорское, Чугуевское, Одесское, Киевское, Рижское, Казанское, Тифлисское, Питербургское, Иркутское, кавалерийские - Елисаветградское, Тверское, казачьи - Оренбургское, Новочеркасское, и Ставропольское училища.

3. Для получения высшего военного образования существовали три академии: Николаевская академия Генерального штаба, Михайловская Артиллерийская академия, Николаевская Инженерная академия.

Таким образом все принятые меры в результате проводимых военных реформ вывели военное образование на новый качественный уровень, позволяющий значительно повысить уровень образования всех военнослужащих 
и получить блестяще образованных офицеров. Кроме того, была достигнута необходимая децентрализация власти военного министерства, так вопросы общего управления высших органов управления гармонично сочетались с полномочиями местных департаментов. Путем включения в военное министерство всех учреждений, которые до этого находились лишь в порядке высшего управления (например, управление военно-учебными заведениями до 1862 года было сосредоточено в штабе Его Императорского Высочества) было достигнуто единство управления. И наконец произошло значительное упрощение организации военного министерства, которое значительно сократило штаты министерства и расширило права начальников главных управлений.

Далеко не все преобразования в военном министерстве достигли желаемого результата, у Д.А.Милютина нашлось много противников и первым из них была сама власть и аристократическое сословие. Нетерпение ко всему прогрессивному и жажда собственной наживы значительно тормозили военные реформы. Так упразднение кадетских корпусов напрямую затрагивали интересы дворянства т.к. в них принимали исключительно детей дворянского сословия и только сохранением Пажского, Финляндского, Оренбургского и Сибирского корпусов был достигнут определенный компромисс. Введенная новыми уставами тактика, которая разрушала расстреливаливаемые во время крымской войны «сомкнутые строи», натыкалась на любовь императора к плац-парадам и вновь во главу угла становилась парадная подготовка с еe равнениями и красотой строевого шага. Необходимое перевооружение войск тормозилось срывами поставок из-за воровства подрядов приближенных к царской фамилии.

Деятельность Дмитрия Алексеевича Милютина на посту военного министра служит прекрасным примером работы государственного деятеля, а его вклад в повышение обороноспособности страны огромен. Заложенный его реформами основательный фундамент новой системы военного управления позволил Русской армии в эпоху царствования императора Александра III добиться блестящих побед, а Российская империя достигла неоспоримое 
лидерство среди других империй. Исторический опыт и методы решения вопросов создания системы управления на государственном уровне и в наше время имеет большое практическое значение, а принципы реформирования вооруженных сил, заложенные в XIX веке актуальны и поныне.

\section{Литература:}

1. Волков С.В. Русский офицерский корпус. - Издательство: Центрполиграф, 2003. $-414 \mathrm{c}$.

2. Взгляд на состояние русских войск // Военный сборник. - Т. I. - СПб., 1858. - C. $12-13$

3. Данилов Н.А. Исторический очерк развития военного управления в России. - СПб., типография товарищества Вольф М.О, 1902. - 680 с.

4. Затворницкий Н.М. Столетие Военного министерства 1802-1902 т.ІІІ. Военные министры и главноуправляющие Военной частью в России с 1701 по 1910 год. - СПб., типография товарищества Вольф М.О, 1911. $320 \mathrm{c}$.

5. Затворницкий Н.М. Столетие военного министерства. Память о членах военного совета. 1802-1902 г. т.3 ч.IV - СПб., типография товарищества Вольф М.О, 1911. - 362 с.

6. Зайончковский А. М. Восточная Война 1853-1856. - СПб.: ООО «Издательство «Полигон», 2002. - 928 с.

7. Каменев А.И. История подготовки офицерских кадров в России. - М.: ВПА им. Ленина, 1990. - 195 с.

8. Керсновский А.А. История русской армии. Т.3,4. - М.:Голос,1994

9. Кедрин В.И. Александровское военное училище 1853-1901. - Типография Лиснера, 1901 - с.250 
10. Лалаев М.С. Исторический очерк военно-учебных заведений, подведомственных Главному их управлению. От основания в России военных школ до исхода первого двадцатипятилетнего благополучного царствования государя императора Александра Николаевича 1700-1880. СПб., Главное управление военно-учебных заведений, 1880. -302 с.

11. Милютин Д.А. Воспоминания. 1860-1862. - М.: Редакция альманаха «Российский Архив», 1999. - 559 с.

12. Трубецкой А. Крымская война. - М. : Ломоносов, 2010. - 320 с.

13. Тарле Е. В. Крымская война: в 2-х т. - М.-Л.: 1941-1944.

14. Щербачев Г. Д. Воспоминания //Русский архив. 1890. Т. I

15. Полное собрание законов Российской Империи т.XXXVIII №39192

16. Полное собрание законов Российской Империи т.XXXVIII № 4007

17. Полное собрание законов Российской Империи т.XXXIX № 41067 